UDC 821.111.08 ^аркин Ф.

81 '38

\author{
Marija Milojkovic ${ }^{*}$ \\ University of Belgrade \\ Faculty of Philology \\ Department of English Language and Literature \\ Belgrade, Serbia
}

\title{
QUENCHED LIGHT, OR SEEING THROUGH A GLASS DARKLY - \\ A COLLOCATION-BASED VIEW OF LARKIN'S ATHEISM AND DEPRESSION
}

\begin{abstract}
This paper uses computational collocation-based analysis to examine Philip Larkin's reputation as a depressive atheist. ${ }^{1}$ After a brief discussion of the term 'collocation', a complete corpus of Larkin's poetry will be analysed for key symbols. This will be compared with a passage from 1 Corinthians 13 describing the transition from an incomplete human state to that of maturity, self-knowledge and perfection. Both will be checked against a reference corpus in the form of a newspaper corpus of 44.5 million words. The nature of transitions in Larkin's poems (whether from day to night, from dissatisfaction to inability or from love to disappointment) will shed light on several questions surrounding his verse, finally showing his persona as a rebellious, doubting and immature Christian.
\end{abstract}

Key words: corpus stylistics, collocation, poetry, Larkin, atheism, depression

E-mail address for correspondence: marija.milojkovic@fil.bg.ac.rs

1 I remain grateful to Bill Louw, University of Zimbabwe, for introducing me to the field of corpus stylistics. I am also grateful to Professor Boris Hlebec, University of Belgrade, for discussing with me the theoretical implications of dynamic collocation, as well as for commenting on this paper. 
Since the paper proposes a collocation-based view of Larkin's poetry, let us consider first what we mean by collocation. J.R. Firth considered collocation as being abstracted at the level of syntax:

Meaning by collocation is an abstraction at the syntagmatic level and is not directly concerned with the conceptual or idea approach to the meaning of words. One of the meanings of night is its collocability with dark (Firth 1957: 181).

If we look at the definition by John Sinclair, we shall see that he usually looks for a word's collocates within the limit of four words to the left and four words to the right:

Collocation is the occurrence of two or more words within a short space of one another in a text. The usual measure of proximity is a maximum of four words intervening (Sinclair 1991: 170).

Since both our sources agree that collocation is not syntax bound but determined by proximity, and one states that collocates influence the word's meaning, then we may agree that in the world of a poet collocates may indeed throw light on the meaning of the word that the poet tends to attach to it. ${ }^{2}$ Williams" statements that "meaning is negotiated by use of contextual features" (Williams 2010: 405) and that collocation "is, as Firth and Sinclair showed, an area central to language" (Williams 2010: 403) is in accordance with Louw's view that 'collocation is instrumentation for literary or fictional worlds and is fairly easily supplied' (Louw 2010: 90).

2 This view of collocation is best summarized by Williams and Millon (2011):

... [T] raditional phraseology, and much pre-corpus lexicography, and corpus linguistics developed on parallel lines. Those lines were effectively drawn together in the Cobuild initiative[...]

Phraseologists and lexicographers seek to tame language so as to list and classify for inclusion in published works. This requires an essentially static vision of collocation where phraseological units are treated as if created ex nihilo and are simply found and classified on purely linguistic grounds as to what may and what may not be termed as a collocation.

The NeoFirthian approach developed by John Sinclair within the context of corpus linguistics is very different in that it places collocation at the very heart of language as an essentially dynamic process in which meanings are created and exploited within textual contexts. The advantage of corpus linguistics is that it allows an analysis of dynamic collocation whilst providing the material for more reductive phraseological or computational exploitation of the data.

(Williams and Millon 2011: 151) 


\section{Look at the following concordance from a corpus of complete poetry} by Philip Larkin (1922-1985), where the search word 'light' is sufficiently explained by its collocates: ${ }^{3}$

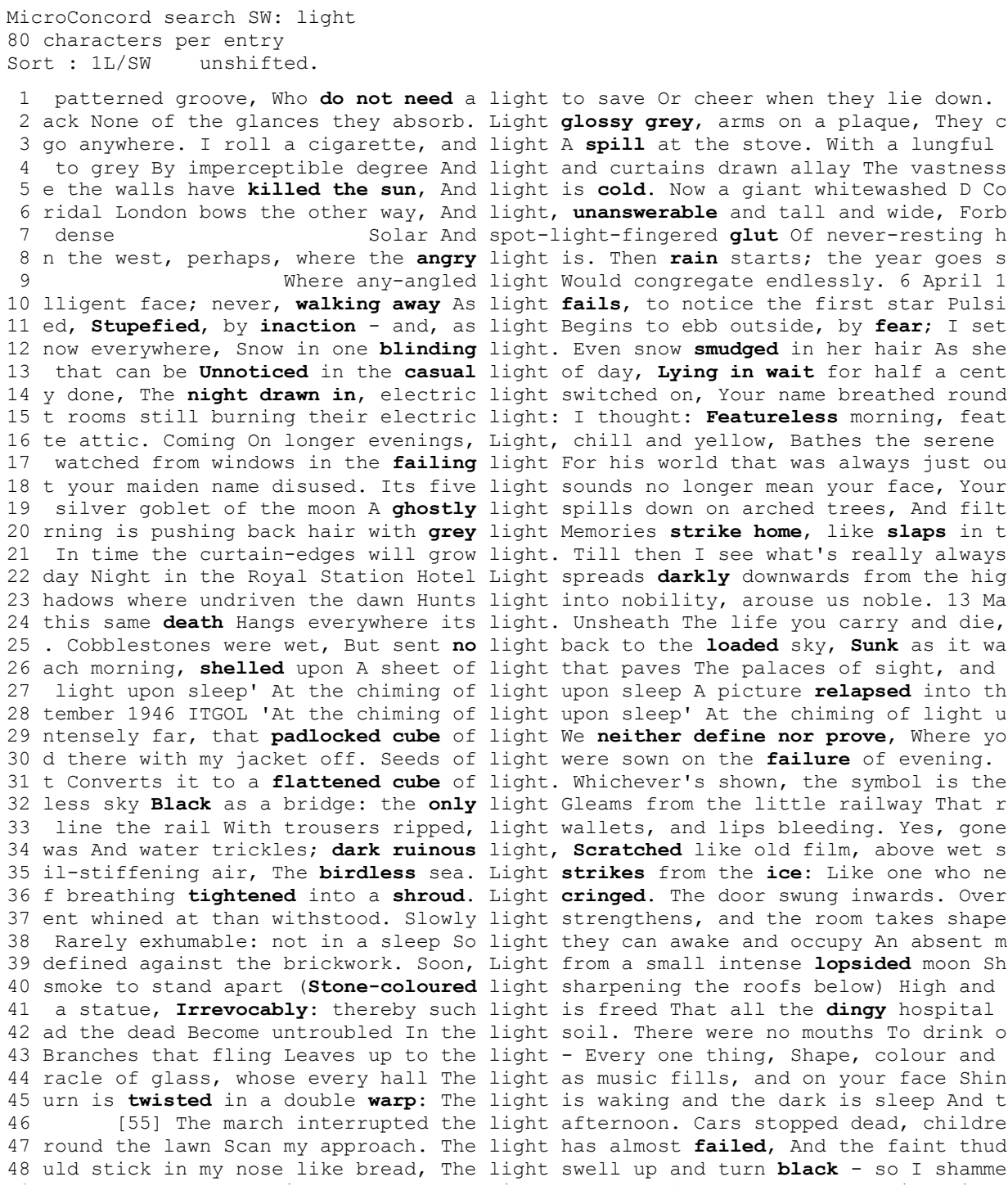

3 The concordances of 'light', 'God', 'day' and 'night' were given to me by Bill Louw, University of Zimbabwe, as well as the complete corpus of Larkin's poetry, based on Anthony Thwaite's edition (Thwaite 1988). 
49 peace, but other things. Beyond the light stand failure and remorse Whispering 50 ? Colonel Sloman's Essex Rifles? The Light Horse of L.S.E.? March ? 1969 'Black 51 old, And the red clubhouse flag. The light, the turf, and all that grows now urg 52 ts indecision. If once it blocks the light, I die. If I could make a single wish 53 finished faces Sink further from the light. No one pretends To want to help you 54 rice of stock. Smoke hangs under the light. The pictures on The walls are comic 55 readths of time. Snow fell, undated. Light Each summer thronged the glass. A bri 56 elf looped with the creep of varying light, Monkey-brown, fish-grey, a string of 57 lay Asking the open door Why it was light outside, Since nobody had put on The 58 of thin continuous dreaming Watching light move? If they don't (and they can't), 59 esque Down stucco sidestreets, Where light is pewter And afternoon mist Brings 1

60 tall ships, wind-mastered, wet with light, Break from an estuary with their cou

Data from the following files:

ZARKIN. CTX

This is how light is seen in the world of Larkin's poetry. ${ }^{4}$ If the reader were to search for lines in which light is shown with more optimism, he/she would find but a few. However, 31 lines out of the 60 found in the corpus are expressly negative. A comparison with John 1:5 may prove relevant: "And the light shineth in darkness; and the darkness comprehended it not." Unsurprisingly, this $20^{\text {th }}$ century English poet is widely regarded as a pessimistic atheist. The concordance with 'God' as the node is no less conclusive:

Microconcord search SW: god
80 characters per entry
Sort : 1L/SW unshifted.
1 that inspired it all, And made him a god. No, he would never fail. Others, of c
2 ortraits of Sex Sun. Tree. Beginning. God in a thicket. Crown. Never-abdicated c
3 e, musty, unignorable silence, Brewed God knows how long. Hatless, I take off My
4 the sky, Asking to die: 'To die, dear God, before a scum of doubt Smear the whol
5 pausing, goes into a prayer Directing God about this eye, that knee. Their heads
6 any nights, as many dawn, If finally God grants the wish. 2 February 950 Dece
7 go on before us, they Are sitting in God's house in comfort, We shall see them
8 ey need; And famous lips interrogated God Concerning franchise in eternity; And
9 And thought, That'll be the life; No God any more, or sweating in the dark Abou
10 ' Let it be understood That 'somehow' God plaits up the threads, Makes 'all for
11 , and lips bleeding. Yes, gone, thank God! Remembering each detail We toss for h
12 tor clenched his fists And swore that God exists, clamping his features stiff wi
13 adio's altarlight The hurried talk to God goes on: Thy Kingdom come, Thy will be
14 mit with his gown and dish Talking to God (who's gone too); the big wish Is to h

Data from the following files:

ZARKIN.CTX

${ }^{4}$ Collocation-based analysis is not restricted to English. For an analysis of Alexander Pushkin in the Russian original, see Milojković (2011: 48-9). 
Marija Milojković Quenched light, or seeing through a glass darkly-a collocation-based ...

This concordance is more helpful than the previous one in establishing the meaning of the node with greater precision. The first negative line is line 4 (collocates in 8 lines out of 14 have been singled out), where light collocates with 'scum of doubt'. Three more lines express doubt, containing 'if finally', 'somehow' and 'hurried' (if the conversation with God is hurried it loses in dignity somewhat). Since the 'scum of doubt' line may not seem conclusive at first sight, the wider context was opened: "To die, dear God, before a scum of doubt / Smear the whole universe, and smudge it out."

The aim of this paper is to present the support or lack of it for Larkin's reputation as an atheistic pessimist. This will be done by checking the complete corpus of Larkin's poetry against the 44.5 million word corpus of the Times newspaper, ${ }^{5}$ as well as against the famous Chapter 13 of 1 Corinthians, in particular the following passage:

9 For we know in part, and we prophesy in part.

10 But when that which is perfect is come, then that which is in part shall be done away.

11 When I was a child, I spake as a child, I understood as a child, I thought as a child: but when I became a man, I put away childish things.

12 For now we see through a glass, darkly; but then face to face: now I know in part; but then shall I know even as also I am known.

13 And now abideth faith, hope, and charity, these three; but the greatest of these is charity.

(The Bible. Cited from Carroll and Prickett 1998: 217-218, emphasis in bold italics added)

If we search for 'faith', 'hope' and 'charity' in Larkin's verse, that will not leave much hope for our attempt to redeem his reputation of an atheist. The word 'charity' is not to be found. The word 'faith' is to be found twice:

\footnotetext{
5 What will be referred to as the Times corpus refers to a newspaper corpus (44.5 million words of running text) of the Times of London for the year 1995 created and distributed informally by the late Tim Johns.
} 


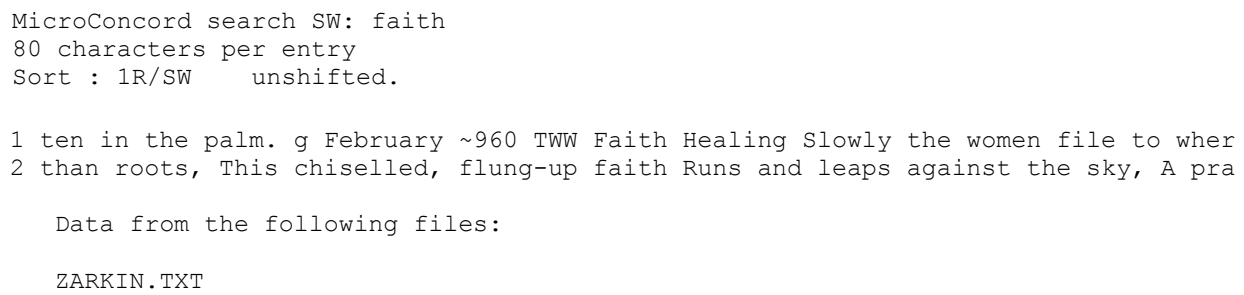

In the first concordance line, 'faith' appears as part of the title 'Faith Healing', a practice that Larkin considered doubtful. The second line is from the beginning of the poem 'A Stone Church Damaged by a Bomb': "Planted deeper than roots,/ This chiselled, flung-up faith/ Runs and leaps against the sky,/ A prayer killed into stone/ Among the always-dying trees..."

The word 'hope' does not leave us much more hopeful. There are nine concordance lines, out of which two are from a jocular last will and testament and two from a birthday poem to a friend. The remaining five lines are all negative: "the last of hope" (line 2), "that long and sickly hope" (line 5), "through doubt from endless hope to hate and terror" (line 7), "all we can hope to leave them now is money" (line 8). Line 2 does not contain obviously pessimistic collocates but the wider context shows that Hope is used in a far more sinister context than in any other poem ('The house on the edge of the serious wood...')

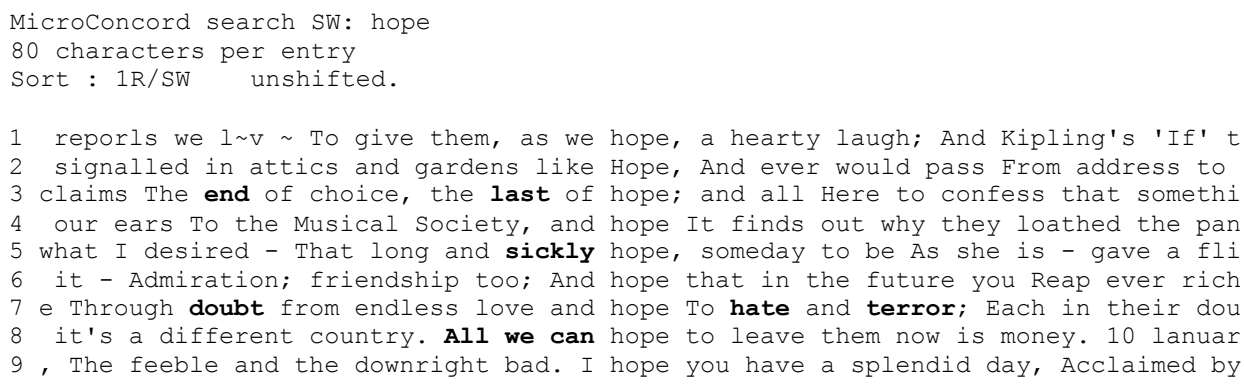


Marija Milojković Quenched light, or seeing through a glass darkly-a collocation-based ...

So far, 1 Corinthians 13 supports the view that Larkin was not a Christian. After all, even if faith does not need to be mentioned explicitly, hope is the foundation and the lighthouse of the religious. Seeing that the collocates of 'light' are very different from what an average person might expect ('angry', 'failing', 'grey', 'dark ruinous'), we know what to anticipate when it comes to the collocates of 'day':

\author{
MicroConcord search SW: day \\ 80 characters per entry \\ Sort : 1R/SW unshifted.
}

[219] 'By day, a lifted study-storehouse' By day, a

2 By day, a lifted study-storehouse' By day, a lifted study-storehouse; night Conv

3 right bad. I hope you have a splendid day, Acclaimed by wheeling gulls at play A

4 ng I got up and it did not. The first day after a death, the new absence Is alwa lack The happiness I had. Now in the day All's ravelled under the sun by the wi 6 oss for half the night, but find next day All's kodak-distant. Easily, then (tho $7 \mathrm{~d}$ for her own attending, And there by day and night with her blithe bone mending

$8 \mathrm{~s}$ thunderstorms, Holds up each summer day and shakes It out suspiciously, lest s

9 With shovel and spade; That each dull day and each despairing act Builds up the

10 her getting away Now she's there all day, And the money he gets for wasting his

11 e time, Half-past eleven on a working day, And these picked out of it; see, as $t$

126 May 1977 [ 207 ] Aubade I work all day, and get half-drunk at night. Waking a

13 ss of night Swamps the bright nervous day, and puts it out. In other times, when

14 and twist, and the pubs wide open all day; And the countryside not caring: The $p$

15 es. Wedding-Wind The wind blew all my wedding-day, And my wedding-night was the

16 ing and the dark is sleep And twice a day before their gate we kneel between the

17 words Then parts out the rest of the day Between bathing and booze and birds Is

$18 \mathrm{~s}$ in our summer wear Brother, and the day Breathes coldly from fields far away A

19 ing provides for. What can it do each day But hunt that imminent door Through wh

20 osite) won't achieve. That's clear as day. But come back late at night, you'll h

214 Febmary 1965 [ 160 ] Administration Day by day your estimation clocks up Who d

22 rotics no one gives you a thought, as day by day You drag your feet, clay-thick

$23 \mathrm{~g}$, but futile,' said his diary, Where day by day his movements were recorded And

24 to join us? In a pig's arse, friend. Day comes to an end. The gas fire breathes

$25 \mathrm{ng}$ steers become old cattle from that day, Electric limits to their widest sense

26 mothers. And so, while summer on this day Enacts her dress rehearsals, Let us fo

27 ess faces: Gold surf of the sun, each day Exhausted through the world, gathers a

28 ld mingle, and the night would not Be day's exhaustion; there would drift about

299 February 1973 HW Show Saturday Grey day fer the Show, but cars jam the narrow

30 ghs up failure, Carries the night and day, fetches Profit from sleep, from skies

31 winds crying for that unbroken field, Day having lifted) Black flowers burst out

32 tempt of good and bad; But one Spring day his land was violated; A bunch of hors

33 futile,' said his diary, Where day by day his movements were recorded And nothin

34 ves and domes travel The slow sky all day. I land to stay here; And the windows

35 ife come along And pour out tea, each day. I don't know what was said; Just hosp

36 -lifting arms. She was slapped up one day in March. A couple of weeks, and her $f$

37 al memory. So it was stale time then, day in, day out, Blue fug in the room, not

$38 \mathrm{n}$ to face the way That led me to this day. Instead of fields and snowcaps And fl

39 screamed. 'Lift through the breaking day' Lift through the breaking day, Wind $t$

40 cancy, Empty inside and out, replaces day. (Like a fuse an impulse busily disint

$41 \mathrm{n}$ be Unnoticed in the casual light of day, Lying in wait for half a century To $\mathrm{S}$

42 and sillier; Much we buy each market day, More still obtain: All, all is carrie

43 lways there: Unresting death, a whole day nearer now, Making all thought impossi

4471969 HW [ 174] The Explosion On the day of the explosion Shadows pointed towar 
$45 \mathrm{y}$. So it was stale time then, day in, day out, Blue fug in the room, nothing to 46 yond the glass The colourless vial of day painlessly spilled My world back after 47 I'd've thought. Must finish now. One day perhaps I'll know What makes you be so 48 Above the sea, the yet more shoreless day, Riddled by wind, trails lit-up galler 49 ents, naturally. Thereafter night and day she came both for the sight of his slo 50 the bed was a hospital bed. Then one day she fell Outside on the sad walk And h $51 \mathrm{xx}$ 'Sinking like sediment through the day' Sinking like sediment through the day 52 lither - Creatures, I cherish you! By day, sky builds Grape-dark over the salt U 53 r's impressive lie - Upon whose every day so many ruined are May could not make 54 ove and money Ways of slow dying. The day spent hunting pig or holding a garden$55 \mathrm{~h}$ observed Celestial recurrences, The day the flowers come, And when the birds $g$ 56 arture: only shadows Move when in the day the sun is seen for an hour, Yet to me 57 omething is always approaching; every day Till then we say, Watching from a bluf 58 ay' Sinking like sediment through the day To leave it clearer, onto the floor of 59 like long hills, a range We ride each day towards, and never reach. 17 NorJember 60 nripe day you bore your head, And the day was plucked and tasted bitter, As if s 61 airborne Did I recall the date - That day when Queen and Minister And Band of Gu $62 \mathrm{~g}$ to catch my Comet one dark November day, Which soon would snatch me from it To 63 with adult enterprise, And on another day will be the past, A valley cropped by 64 eaking day' Lift through the breaking day, Wind that pursues the dawn: Under nig 65 between felt-hatted mums Whose weekly day-excursion yields Baby-sized parcels, b $66 \mathrm{~W}$, TNS, ITGOL 'So through that unripe day you bore your head' So through that un 67 ore your head' So through that unripe day you bore your head, And the day was pl 68 No one gives you a thought, as day by day You drag your feet, clay-thick with mi 69 till might trace Uncalled-for to this day Your person, your place. 10 oc ober 19 70 ry 1965 [ 160 ] Administration Day by day your estimation clocks up Who deserves 71 hame out of hiding. All the unhurried day Your mind lay open like a drawer of kn

Data from the following files:

ZARKIN.TXT

The overall impression is that of routine, often frustrating. This is certainly a sign of depression. All the seemingly ambiguous contexts were opened to confirm the initial impression, and it was confirmed in each case. For instance, line 40 comes from 'Sinking like sediment through the day': "Sinking like sediment through the day/ to leave it clearer, onto the floor of the flask/ (Vast summer vessel) settles a bitter carpet -/ Horror of life."

If this is Larkin's vision of day, the source of light, what is then his view of night?

Microconcord search SW: night

80 characters per entry

Sort : $1 \mathrm{R} / \mathrm{SW}$ unshifted.

1 cape, or perish saying no. Midsummer Night, 1940 The sun falls behind Wales; the 2 and choose wrong; And so we rise. At night again they sound, Calling the travell

3 e it ploughs up failure, Carries the night and day, fetches profit from sleep, f

4 t Outpatients, naturally. Thereafter night and day she came both for the sight 0

5 , And reads the Modern Boy in bed at night. And when, upon the cricket field, he

6 among the wealthy sneered, on such a night as this twilight and doubt Would ming

7 culptured on England, wait again for night As a deserted beach the tide that smo 
Marija Milojković Quenched light, or seeing through a glass darkly-a collocation-based ...

8 d last bun: How you had laughed, the night before you left; All your potentialit

9 patterns on the curtains, drawn The night before. The milk's been on the step,

10 rs sang in their sockets through the night: 'Blow bright, blow bright The coal 0

11 ing each detail We toss for half the night, but find next day All's kodak-distan

12 disperses. But We, on this midsummer night, can sneer In union at mind that coul

13 afternoons. New strong Rain-bearing night-winds come: then Leaves chase warm bu

$14 \mathrm{alk}$ on this or that excuse, Till the night comes to rest while some high bell is

15 home existed) letters of exile: Now Night comes on. Waves fold behind villages.

16 ' By day, a lifted study-storehouse; night Converts it to a flattened cube of li

17 till: bowing, the woods bemoan; Dark night creeps in, and leaves the world alone 18 about it when the meal lay done, The night drawn in, electric light switched on, 19 ht' Or resolution's aid. Around, the night drops swiftly down Its veils; does no 20 steps cold. The rain drips drearily; night's fingers spin $\mathbf{A}$ web of drifting mist 21 disregard their blowing, or if, this night, happiness too is going. He Hears tha 22 small blunt footprints come and go. Night has left no more to show, Not the can 23 Black flowers burst out wherever the night has knelt. 15 December 1945 ITGOL

24 hey burn on, impersonal, through the night, Hearing the hours slowly topple past $25 \mathrm{y}$, Wind that pursues the dawn: Under night's heedless stone Houses and river lay 26 treet of tramways and bells. But one night I heard the feet. Step after step the 27 ur version' of 'these incidents last night'? I try the door of where I used to 1 28 e walls of my room rise, it is still night, I have woken again before the word w 29 hours pass: if I'd gone by boat last night I'd be there now. Well, it's too late 30 pause' Out in the lane I pause: the night Impenetrable round me stands, And ove 31. 24 Novemoer 1965 HW [ 162 ] Friday Night in the Royal Station Hotel Light spre 32 my heart. 12 October 1944 TNS, ITGOL Night- M usic At one the wind rose, And wit 33 users Spread the stands of Modes For Night: Machine-embroidered, thin as blouses 34 ht: Featureless morning, featureless night. Misjudgment: for the stones slept, a 35 thankful springs' Coming at last to night's most thankful springs, I meet a run 36 runken boatswain. 'Coming at last to night's most thankful springs' Coming at la 37 ve no proper names: Men out alone at night Never look up at them For guidance or 38 Hearing this last word, There was no lambing-night, No gale-driven bird Nor fros $39 \mathrm{~h}$ industrial shadows And traffic all night north; swerving through fields Too th $40 \mathrm{~m}$ back, and how it will end ? Not at night? Not when the strangers come? Never, 41 night?' Why did I dream of you last night? Now morning is pushing back hair wit $42 \mathrm{ng}$-day, And my wedding-night was the night of the high wind; And a stable door w 43 ait But for the coming of the winter night of deep December; blowing o'er the gr 44 reeze That wanders through the quiet night of June. Now time should stop; the we $45 \mathrm{u}$ have your innocent-guilty-innocent night of switching partners in your own sad 46 done, Produce our lives beyond this night, Open our eyes again to sun. Unhinder 47 ar the feet of lonely walkers in the night or lingering pairs; Girls and their $\mathrm{s}$ 48 things back to when they danced all night, or went to their wedding, or sloped 49 ber 1938 [ 226 ] Summer Nocturne Now night perfumes lie upon the air, As rests $t$ 50 he night puts twenty veils' When the night puts twenty veils over the sun, and $t$ 51 so many years ago. 1231 ] 'When the night puts twenty veils' When the night put 52 les for a cancer; or on some Advised night see walking a dead one? Power of some 53 I was sad That any man or beast that night should lack The happiness I had. Now 54 death has merely made beautiful, And night skies so brilliantly spread-eagled Wi 55 x. beforelune Iy39 Street Lamps When night slinks, like a puma, down the sky, An $56 \mathrm{~g}$ sea-pictures - Keep it all off! By night, snow swerves (O loose moth world) Th $57 \mathrm{r}$ the carrying, for its own sake, Is night so gifted? Mind never met Image of de 58 And everywhere the stifling mass of night Swamps the bright nervous day, and pu 59 t fraying cliffs of water or late at night sweet under the differently-swung sta 6011 as a veil; But I have watched all night The fire grow silent, The grey ash so 61 work all day, and get half-drunk at night. Waking at four to soundless dark, I 62 wind blew all my wedding-day, And my wedding-night was the night of the high win 63 nds Show after four o'clock, Time of night when straying winds Trouble the dark. 64 [ 230 ] 'Why did I dream of you last night?' Why did I dream of you last night? 65 land. Are you prepared for what the night will bring? The stranger who will nev 66 me To walk on the chilled shore of a night with no memory, Till your voice forso 67 That, unopposed at last, return Each night with cancelled promises They want ren 
68 own attending, And there by day and night with her blithe bone mending watched

69 leasures I would give, if this sweet night Would ever stay, cooled by the pale m

70 ight and doubt Would mingle, and the night would not Be day's exhaustion; there

71 we meet How can I tell you that Last night you came Unbidden, in a dream? And ho

72 clear as day. But come back late at night, You'll hear a curious counter-whispe

Data from the following files:

ZARKIN.TXT

One can hardly claim that the image of night is optimistic or hopeful, but it is certainly less uniform than that of day, and also gentler and softer. The images are more varied, fire and light are sometimes mentioned, as well as dreams of 'you' which the poet does not find unpleasant. Rain, wind, snow and leaves are involved, but also the quiet summer night of lingering pairs. Night often becomes an active agent, it converts, creeps, fingers, spins, kneels, puts twenty veils over the sun, slinks like a puma down the sky. The general impression is that of mystery. Line 17's wider context may at first sight seem baffling. The poem 'Winter Nocturne' deals with the advent of night, an event often mentioned in Larkin's verse. Finally it arrives:

The rain falls still: bowing, the woods bemoan;

Dark night creeps in, and leaves the world alone.

The whole poem is about the period of transition between day and night, culminating in its arrival. How then can it at the very moment of arrival leave the world alone? It is unlikely that Larkin, who is known to have written 500 words a day after homework as a teenager, could have left in such an inconsistency. Apart from the meaning of 'leave something in a particular state' (which implies that the world is alone now night has entered it), Larkin must also have had in mind the meaning 'not bother or interfere with, leave be'. The word 'leave' co-selected with 'alone' was searched in the Times corpus. 150 concordance lines were found. In 15 of them the context was literal (e.g. leave a child alone, i.e. without adult supervision). Out of the remaining 135 lines 99 pointed to the conclusion that leaving something or someone alone in the sense of not interfering with it is a good idea, because of the unwelcome consequences of not leaving alone. Therefore, the poem about the advent of night describing the unrest felt in nature prior to its arrival states clearly that night, by leaving the world in the state of loneliness, does a good thing. 
Marija Milojković Quenched light, or seeing through a glass darkly-a collocation-based ...

Indicatively, the number of occurrences of 'day' and 'night' in Larkin's poetry is equal: 71 and 72 . This must mean that they played an equal part in his world and were taken equally seriously. What is the nature of their relationship in his world and does Larkin perceive night as more favourable? Let us open the context of line 58 to see the relationship between day and night:

And everywhere the stifling mass of night

Swamps the bright nervous day and puts it out.

It comes from the poem 'Midsummer Night' which again deals with transition between day and night. The phrase 'it out' was searched in the Times corpus. 195 lines were found. 'Out' was mostly a particle belonging to a phrasal verb, with 'it' as its direct object, like 'carry it out', 'pull it out', 'sort it out'. Mostly the underlying argument in the concordance lines was that the action described by the phrasal verb was intended to solve a problem. Four concordance lines contained 'put it out'. In all four lines, what needed to be put out was a great fire. Thus, night, "swamping" bright nervous day, may be interpreted as doing the poet a favour, extinguishing the great calamity - day. The day is nervous because it may be put out but also because it might be making the poet nervous too. This is, of course, an allusion to St John: "And the light shineth in darkness, and the darkness comprehended it not". In Larkin's world, night quenches the calamitous day. Why does it need quenching? The poem answers the question.

The poet proceeds to explain that in the past night did not use to be "day's exhaustion" because it continued to distress the minds of men. Stories of the supernatural were told at night, he says. Now we may laugh, but we have thought of our own monstrosities, the dynamite and "Fire!" of war:

The angels yawning in an empty heaven;

Alternate shows of dynamite and rain;

And choosing forced on free will: fire or ice.

This ending to the poem at first leaves us in doubt of Larkin's choice. We know that fire in this poem's world means 'day'. 'Ice', therefore, must mean 'night'. This is confirmed by another poem - 'The North Ship', in which the ship sailing to the north goes "into the unforgiving sea". The northdeath parallel combined with the fire-ice opposition must mean that ice, 
in all its undemanding perfection, means 'death'. Larkin laments the fact that his free will is limited by such a choice. Heaven is empty because it does not admit the undecided (remember "guarda e passa" in Canto III of Dante's Inferno). Larkin's forced choice must exclude the doubt which is so characteristic of him. Is he choosing ice? Paradoxically, by choosing fire (day) in the poem one chooses death which is a door to heaven. By choosing ice one chooses death which is the death of the north ship lost in the unforgiving sea. The logic of the poem demands that Larkin should choose fire. We are dealing with a rebellious and complaining poet and a Christian.

The question why 'day' is perceived as a calamity is perhaps best answered in 'After-Dinner Remarks'. It appears to have been written on an evening (again):

And now the evening ambles near,

Softly, through the scented air,

Laying by the tautened fear:

Peace sliding from above.

The "tautened fear", of course, belongs to day, and the evening is a welcome transition from day to night. Why? The poem answers the question: “... living is a dreadful thing, and a dreadful thing it is". Perhaps when an Englishman uses the words 'dreadful thing' he does not really mean it? The Times corpus showed seven concordance lines:

Line 1 - rain combined with very bad depression.

Line 2 - unexpected death of an adolescent's parent.

Line 3 - a negative critique of an unprofessionally done book.

Line 4 - a murdered young woman.

Line 5 - the mental breakdown of a young girl.

Line 6 - a badly beaten woman.

Line 7 - torture.

Thus, when Larkin says that living is a dreadful thing he obviously means it. Why does he find it dreadful?

On this day, previously to the soliloquy, the persona, "in the face of time", seems to have missed an opportunity to make his feelings and desires known to the woman he loves, or failed to take steps that may have brought them closer together. That makes him take an all-encompassing 
Marija Milojković Quenched light, or seeing through a glass darkly-a collocation-based ...

look at his entire life full of doubt and inaction, and assume that future will bring nothing but loneliness. He wonders if he is

A keyhole made without a key

A poem none can read or say

A gate none open wide to see

The fountains and the trees.

The images of a keyhole and a gate as transitions to fountains and trees are reminiscent of entering Paradise, or the moment in 1 Corinthians when "seeing through a glass darkly" becomes "face to face". Larkin wishes to be "known" and fails as a result of too much doubting. The ending to the poem explains how night alleviates day's frustrations:

Around, the night drops swiftly down

Its veils, does not condemn

Or praise the different actions done,

The hour that strikes across the town

Caresses all and injures none

As sleep approaches them.

Day is a source of distress and frustration through inaction and doubt resulting in loneliness and fear that one will never "be known", but night comforts all and brings peace to all regardless of their mistakes. When we remember the collocates of 'day' and 'night' in both concordances, we will see how they fit into this interpretation.

That Larkin was aware of the quoted passage from 1 Corinthians 13 mentioning the transition to true perception and knowledge of oneself and others is confirmed by several references. 'After-Dinner Remarks' contains one:

I saw my life as in a glass:

Set to music (negro jazz),

Coloured by culture and by gas,

The idea of a kiss... 
It is obvious from this example as it will be from others that to Larkin the transition to knowledge, and, therefore, happiness, is the transition to a fulfilled relationship that he, for some reason, fails to achieve. Before proceeding to justify this assumption, another poem is worth quoting. The short ironic piece 'Naturally the Foundation will Bear Your Expenses' contains the following lines: "Perceiving Chatto darkly/ Through the mirror of the Third." The persona, a cynical and successful academic travelling abroad, expresses his ambition to be published, which he might fulfil by previously appearing on the BBC Third Programme. This example is included here to support the assumption that Larkin was fully aware of the passage quoted from 1 Corinthians 13 and it being a transition to happiness (the cynical academic regards self-knowledge and happiness as attainable through publicity and fame). Our notion that the mirror in Larkin represents a transition to a relationship which is never achieved is supported by another poem, 'The Dance'.

The persona of the poem arrives at a dance at which he is to meet the woman he is interested in and immediately glances at his own appearance in the mirror, which leaves him far from happy:

That in the darkening mirror sees

\section{... my equally contemptuous glance}

The shame of evening trousers, evening tie.

Indicatively, the persona sees his reflection in the mirror against the background of a jazz band, which reminds us only too well of 'AfterDinner Remarks'. We are to be reminded of the same poem again, when the hero elbows his way through the crowd to the woman he loves. In her gestures he recognises the speech of invitation, and the moment freezes. This timeless situation could become permanent, a transition to eternity (a reminder of 1 Corinthians 13?), but their interaction is rudely interrupted, and the hero allows himself to be led away to join a conversation that does not interest him. The glass, or 'darkening mirror's, has again served

${ }^{6}$ It is worth noting here that forms of 'mirror' appear in Larkin's poetry five times. Apart from the references to Radio 3 and 'the shame of evening trousers', there is a reference to 'harmless mirrors' in 'I am washed upon a rock' and two references that are sinister: in 'A house on the edge of a serious wood' and in 'Time and Space were only their disguises'. 
Marija Milojković Quenched light, or seeing through a glass darkly-a collocation-based ...

as transition. To what? A frustrated love experience. Happiness and selfknowledge are again refused him.

"Face to face" appears twice in Larkin's corpus. Once in the poem 'Explosion' (we have to infer that it is about coal-miners as they are, characteristically, never mentioned as such):

The dead go on before us, they

Are sitting in God's house in comfort,

We shall see them face to face -

Plain as lettering in the chapels...

If we are left in doubt by these lines as to whether Larkin is being serious and respectful in his obvious reference to 1 Corinthians (and this passage shows how well he was aware of it and how he understood it), the last line mentioning the "unbroken eggs" of one of them sets us straight.

The other mention of "face to face" supports our previous speculations. In 'Reasons for Attendance' the hero is drawn to the "lighted glass" to watch young dancers ("all under twenty-five", he says) "shifting intently face to flushed face". This is another direct allusion. As the persona, characteristically, debates with himself whether to go in:

...Why be out here?

But then, why be in there? Sex, yes, but what is sex?

and goes on to convince himself that sex is not everything, we recognise a familiar pattern. The glass is a marker of transition, the transition being to "face to flushed face" and evoking the thoughts of sex in the persona. This is Larkin's 'charity' and knowledge attainable if the desired transition is accomplished - sexual love. "Face to flushed face" is not the same as "face to face". It is more physical and might bring about change(s) of partners.

The word 'charity' appearing in 1st Corinthians is always rightly understood as 'love' meaning 'agape', universal love. 'Charity' never appears in Larkin's verse, but 'love' does. What kind of love?

Larkin's corpus gives 49 concordance lines. 34 of them express disappointment. If we open wider contexts, only one optimistic line remains. The wider context of each line was opened to find out what kind of love Larkin means. Only five lines did not mean man-woman love. Two 
of these refer to close ties - with family members and close friends (both in the context of hospitals and the possibility of death). These poems are 'Compline' (1950) and 'Ambulances' (1961). Two lines mean 'agape', universal love. The poems are 'New Year Poem' (1940) and 'Faith Healing' (1960). Both of these poems reveal that Larkin fully understood the concept of 'agape'. The optimistic line, the only optimistic one referring to love in the whole of Larkin's poetry, is from 'When first we faced, and touching showed...'. The years of the poems show that Larkin's view of love and use of the word did not change with time.

The first 130 concordance lines from the Times corpus featuring the word 'love' were studied to see in what meaning the word 'love' is used there. If we discard all lines mentioning 'love affair' (in more than 50\% of the lines used delexically, e.g. 'the Edwardian love affair with the past'), 57 lines remain. Of these, family love is mentioned three times, romantic love 33 times, and anything close to 'agape' once. This one example is a quotation of Samuel Johnson saying: "I am willing to love all mankind, except an American". So much for universal love and the British newspaper reading audience.

Larkin's poetry is strictly and candidly autobiographical. A collocational analysis of the complete corpus of his verse shows him as indeed suffering from depression and lack of hope. Night relieves the persona of day's tortures and leaves him in the welcome state of loneliness after yet another attempt to complete the desired transition to the state of 'face to face'. Larkin was aware of 1 Corinthians 13 and generally used biblical references in his poetry, in particular the 'mirror' episode ('Naturally the Foundation will Bear Your Expenses', 'Explosion'), although the extent to which mirrors or glass seem consistently to appear in his verse at crucial moments of transition is arguably an unconscious parallel. His notion of happiness appears to differ from that of 1 Corinthians 13 in that he viewed it as man-woman physical love. The poems show that the encounters that are reminiscent of 1 Corinthians 13 do not bring the persona the wished-for sense of self-knowledge prophesied in the biblical chapter. The persona does not mature through his encounters. His notion of love never really reaches that of 'agape'. His source of frustration must also be seen in the fact that he dislikes mirrors and finds his reflection in them dissatisfying, figuratively as well as literally. That is in accordance with the point of view of a man who finds physical love essential to happiness. As for his supposed atheism, he does express grave doubt. The 
Marija Milojković Quenched light, or seeing through a glass darkly-a collocation-based ...

doubt, however, is of a gnawing nature, as he obviously rather doubts God's justice than his very existence, as poems 'Explosion' (where the reference to 'face to face' is used sarcastically) and 'Midsummer Night' show. When forced to choose between fire and ice, or day and night, he, despite the greatest reluctance, chooses day. Thus, fear of living is overcome by faith, while St Paul still tells us that without charity (Greek agape, Latin caritas) it will avail us little. And charity, he tells us, never fails.

\section{References}

Carroll, C. and S. Prickett (eds.) (1998). The Bible. Authorised King James Version with Apocrypha. Oxford: OUP.

Firth, J. R. (1957). Papers in Linguistics 1934-1951. Oxford: OUP.

Sinclair, J. M. (1991). Corpus, Concordance Collocation. Oxford: OUP.

Louw, W. E. (2010). Collocation as Instrumentation for Meaning: A Scientific Fact. In: W. van Peer, V. Viana and S. Zyngier (eds.), Digital Learning Methods and Technologies. Hershey, PA.: IGI Global, 79-101.

Milojković M. (2011). Semantic Prosody and Subtext as Universal, Collocation-based Instrumentation for Meaning and Literary Worlds. In: V. P. Zakharov (ed.), Труды международной конферениии «Корпусная лингвистика - 2011», St Petersburg: St Petersburg State University, Faculty of Philology, 47-52.

Thwaite, A. (ed.) (1988). The Collected Poetry of Philip Larkin. London: Faber and Faber.

Williams, G. (2010). Many Rooms with Corpora. International Journal of Corpus Linguistics 15:3, 400-407.

Williams G. and C. Millon (2011). Palmer, Firth and Internet: Drawing Together Collocational Threads. Paper presented at the 2011 Corpus Linguistics conference, Discourse and Corpus Linguistics, held in Birmingham, England, 20-22 July 2011. The CL2011 Book of Abstracts available at $h t t p: / / c l 2011$.org.uk/abstracts.pdf.

Received: 15 June, 2011

Accepted for publication: 15 October, 2011 


\title{
Марија Милојковић
}

\author{
СВЕТЛОСТ ОБУЗЕТА ТАМОМ ИЛИ \\ ПОГЛЕД КАО КРОЗ СТАКЛО У ЗАГОНЕТКИ - \\ КОЛОКАЦИЈСКА АНАЛИЗА ЛАРКИНОВОГ АТЕИЗМА И ДЕПРЕСИЈЕ
}

\section{Сажетак}

Рад се бави корпусном колокацијском анализом да би потврдио или оповргао популарно мишљење да је познати енглески песник двадесетог века Филип Ларкин био депресивни атеиста. Да би се ова анализа боље фокусирала, кључни симболи у корпусу целокупне Ларкинове поезије се посматрају и на позадини познатог одломка из Прве Павлове посланице Коринћанима који описује прелаз из несавршеног људског стања у стање самоспознаје, зрелости и божанске љубави. Корпусно-стилистичка методологија се огледа и у поређењу Ларкиновог корпуса с референтним корпусом - новина Тајмс за 1995. годину, који садржи 44,5 милиона речи. Транзиције у Ларкиновим песмама приказаће његовог јунака као бунтовног, неодлучног и незрелог - хришћанина.

Кључне речи: корпусна стилистика, колокација, поезија, Ларкин, атеизам, депресија 